\title{
An interdisciplinary view of the long-term evolution of repository systems across scales: the iCROSS project
}

\author{
Dirk Bosbach ${ }^{1}$, Horst Geckeis ${ }^{2}$, Frank Heberling ${ }^{2}$, Olaf Kolditz ${ }^{3}$, Michael Kühn ${ }^{4}$, Katharina Müller ${ }^{5}$, \\ Thorsten Stumpf ${ }^{5}$, and the iCROSS team ${ }^{+}$ \\ ${ }^{1}$ Institut für Energie- und Klimaforschung - Nukleare Entsorgung und Reaktorsicherheit (IEK-6), \\ Forschungszentrum Jülich (FZJ),Jülich, Germany \\ ${ }^{2}$ Institute for Nuclear Waste Disposal (INE), Karlsruhe Institute of Technology (KIT), Karlsruhe, Germany \\ ${ }^{3}$ Department of Environmental Informatics (ENVINF), Helmholtz Centre for Environmental Research (UFZ), \\ Leipzig, Germany \\ ${ }^{4}$ Deutsches GeoForschungsZentrum (GFZ), Potsdam, Germany \\ ${ }^{5}$ Institut für Ressourcenökologie (IRE), Helmholtz-Zentrum Dresden-Rossendorf (HZDR), \\ Dresden-Rossendorf, Germany \\ $\boldsymbol{+}_{\mathrm{A}}$ full list appears in the team list section.
}

Correspondence: Horst Geckeis (horst.geckeis@kit.edu)

Published: 10 November 2021

\begin{abstract}
The interdisciplinary project "Integrity of nuclear waste repository systems - Cross-scale system understanding and analysis (iCROSS)" combines research competencies of Helmholtz scientists related to the topics of nuclear, geosciences, biosciences and environmental simulations in collaborations overarching the research fields energy and earth and environment. The focus is to understand and analyze close-to-real long-term evolutionary pathways of radioactive waste repositories across nanoscales to repository scales.

The project is subdivided into work packages dealing with laboratory studies, field experiments in underground research laboratories (URLs), advanced modelling studies and the integration and alignment of data and information using virtual reality methods. In this sense, the project structure aims at a holistic view on relevant processes across scales in order to comprehensively simulate potential repository evolutions.

Within the multi-barrier system of a repository for heat-generating radioactive waste, a number of complex reactions proceed, including dissolution, redox processes, biochemical reactions, gas evolution and solid/liquid interface and (co)precipitation reactions. At the same time, thermal and external mechanical stress has an impact on the conditions in a deep geological repository. All those processes are highly coupled, with multiple interdependencies on various scales and have a strong impact on radionuclide mobility and retention. In recent years, substantial progress was achieved in describing coupled thermal-hydro-mechanical-chemical-biological (THM/CB) processes in numerical simulations. A realistic and concise description of these coupled processes on different time and spatial scales is, at present, a largely unresolved scientific and computational challenge. The close interaction of experimental and simulation teams aims at a more accurate quantification and assessment of processes and thus, the reduction of uncertainties and of conservative assumptions and eventually to a close-to-real perception of the repository evolution.
\end{abstract}

One focus of iCROSS is directed to relevant processes in a clay rock repository. In this context, the iCROSS team became a full member of the international Mont Terri consortium and worked in close collaboration with international and German institutions in URL projects. Respective experiments specifically deal with coupled processes at the reactive interfaces in a repository near field (e.g. the steel/bentonite and bentonite/concrete interfaces). Within iCROSS, the impact of secondary phase formation on radionuclide transport is investigated. At Mont Terri, experiments are in preparation to study radionuclide transport phenomena in clay rock formations within temperature gradients and in facies exhibiting significant heterogeneities on different scales (nm to $\mathrm{cm}$ ). 
Beside those studies, high resolution exploration methods for rock characterization are developed and tested and the effect of temperature and other boundary conditions on the strength, creep properties and healing of faults within Opalinus clay are quantified. Multiphysics models coupled to reactive transport simulation have been further developed and applied to laboratory and field experiments. Results are digitally analyzed and illustrated in a visualization center, in order to enhance the comprehension of coupled processes in repository systems across scales.

The present contribution provides an overview on the project and reports selected results. The impact of considering complex coupled processes in repository subsystems for the assessment of the integrity of a given (generic) repository arrangement is discussed.

Kurzfassung. Im interdisziplinären Projekt iCROSS (,Integrität von Endlagern für nukleare Abfälle - Übergreifendes Systemverständnis und Analyse") werden Forschungskompetenzen von Wissenschaftlern der Helmholtz-Institute mit den Themen Nuklearwissenschaften, Geowissenschaften, Biowissenschaften und Umweltsimulationen in einer die Forschungsbereiche Energie sowie Erde und Umwelt übergreifenden Zusammenarbeit kombiniert. Der Fokus richtet sich darauf, realitätsnahe Langzeitentwicklungspfade von Endlagern für radioaktive Abfälle von der Nano- bis zur Endlagerskala zu verstehen und auszuwerten.

Das Projekt ist unterteilt in Arbeitspakete zu Laborstudien, Feldexperimenten in unterirdischen Forschungslaboren (URL), fortgeschrittenen Modellierungsstudien und der Integration sowie der Ausrichtung von Daten und Informationen unter Verwendung von Methoden der virtuellen Realität. In diesem Sinne zielt die Projektstruktur auf eine ganzheitliche Sicht auf relevante Prozesse über Skalen hinweg ab, um potenzielle Entwicklungen von Endlagern umfassend zu simulieren.

Innerhalb des Multi-Barrieren-Systems eines Endlagers für wärmeerzeugende radioaktive Abfälle laufen eine Reihe komplexer Reaktionen, einschließlich Zerfallsreaktionen, Redoxreaktionen, biochemischer Reaktionen, Gasentwicklung und Fest-Flüssig-Grenzflächen- sowie (Ko-)Präzipitationsreaktionen ab. Gleichzeitig haben thermische und externe mechanische Belastungen einen Einfluss auf die Bedingungen in einem geologischen Tiefenlager. Sämtliche dieser Prozesse sind eng miteinander verbunden - mit multiplen Interdependenzen auf verschiedenen Ebenen - und haben einen großen Einfluss auf die Radionuklidmobilität und -retention. In den vergangenen Jahren wurden wesentliche Fortschritte bei der Beschreibung gekoppelter thermo-hydromechanischchemisch-biologischer (THM/CB-)Prozesse in numerischen Simulationen erzielt. Eine realistische Beschreibung dieser gekoppelten Prozesse auf unterschiedlichen Zeit- und Raumskalen ist zum gegenwärtigen Zeitpunkt eine großenteils ungelöste wissenschaftliche und rechnerische Herausforderung. Die enge Interaktion von Experimentier- und Simulationsteams zielt auf eine genauere Quantifizierung und Beurteilung von Prozessen ab und somit auf die Verminderung von Ungewissheiten und von konservativen Annahmen und schließlich auf eine realitätsnahe Wahrnehmung der Entwicklung des Endlagers.

Ein Fokus von iCROSS richtet sich auf relevante Prozesse in einem Tongestein-Endlager. In diesem Zusammenhang wurde das iCROSS-Team Vollmitglied des internationalen Mont-Terri-Konsortiums und arbeitet in enger Kooperation mit internationalen und deutschen Institutionen in URL-Projekten zusammen. Die entsprechenden Experimente befassen sich insbesondere mit gekoppelten Prozessen an den reaktiven Grenzflächen im Nahfeld eines Endlagers (z. B. die Stahl-Bentonit- und Bentonit-Beton-Grenzflächen). Innerhalb von iCROSS werden die Auswirkungen der Sekundärphasenbildung auf den Radionuklidtransport untersucht. Im Mont-Terri-Labor befinden sich Experimente in Vorbereitung, um Radionuklidtransportphänomene in Tongesteinsformationen innerhalb von Temperaturgradienten und angesichts erheblicher Heterogenitäten in unterschiedlichen Maßstäben ( $\mathrm{nm}$ bis $\mathrm{cm}$ ) zu untersuchen. Neben diesen Untersuchungen werden hochauflösende Untersuchungsmethoden für die Gesteinscharakterisierung entwickelt und geprüft, und die Auswirkungen von Temperatur und anderen Randbedingungen auf die Festigkeit, Kriecheigenschaften und Heilung von Verwerfungen innerhalb von Opalinus-Ton werden quantifiziert. Multiphysikalische Modelle in Kombination mit reaktiver Transportsimulation werden weiterentwickelt worden und in Labor- sowie Feldexperimenten eingesetzt. Die Ergebnisse werden digital ausgewertet und in einem Visualisierungszentrum dargestellt, um das Verständnis gekoppelter Prozesse in Endlagersystemen skalenübergreifend zu verbessern.

Der vorliegende Beitrag bietet einen Überblick über das Projekt und legt ausgewählte Ergebnisse dar. Die Auswirkungen der Betrachtung komplexer gekoppelter Prozesse in Endlager-Subsystemen auf die Beurteilung der Integrität einer gegebenen exemplarischen Endlageranordnung werden erörtert. 
Team list. The iCROSS team consists of individal Helmholtz institutes.

Acknowledgements. The authors would like to thank all colleagues of the iCROSS teams in the individal Helmholtz institutes for their contributions to the project. We gratefully acknowledge the help and support of all collaborating partners. Specifically we would like to thank the URL teams, notably the consortium of the Mt Terri URL, Switzerland, and our funding organisations.
Financial support. This research has been supported by the Helmholtz Association (grant no. SO-093) and the Bundesministerium für Bildung und Forschung (grant no. 02 NUK $053 \mathrm{C}$ ). 